\title{
Composts and Water Extracts of Lignocellulosic Composts in the Aspect of Fertilization, Humus-Forming, Sanitary, Phytosanitary and Phytotoxicity Value Assessment
}

\author{
Justyna Bohacz ${ }^{1}$
}

Received: 28 January 2018 / Accepted: 10 May 2018 / Published online: 15 May 2018

(c) The Author(s) 2018

\begin{abstract}
Purpose Lignocellulosic biomass waste is produced in large quantities and only a small part is used for utility purposes. The aim of the work was to assess the fertilization value of the solid fraction and water extract of lignocellulosic composts. Methods Compost I contained $42.86 \%$ pine bark, $34.28 \%$ grass, $20.0 \%$ sawdust and $2.86 \%$ chicken feathers; compost II contained $25.54 \%$ pine bark, $10.63 \%$ wheat straw, $51.07 \%$ sawdust and $12.76 \%$ chicken feathers. Seldom described physical properties and phytosanitary and sanitary status of composts as well as macro- and micronutrients and heavy metals concentrations were determined in the solid fraction and water extracts of composts and their impact on the germination of Lepidium sativum L. using PC analysis.

Results Composts were characterized by good physical properties and a light product, safe phytosanitary status, which was related to the prevalence of potentially antagonistic fungi, especially in compost II. The frequency of Aspergillus fumigatus, considered an opportunistic human pathogen, decreased during the composting. Heavy metal concentrations did not exceed permissible values for improvers and cultivation media in the solid and aqueous compost fractions. The tested composts were sanitary safe. Both composts were non-toxic to plants, because the germination index in compost I was 70-195\% and 95-195\% in compost II. PCA analysis demonstrated that the majority of micro- and macronutrients and heavy metals had a significantly negative effect on root elongation and germination of the test plant (cress) seeds, especially in compost I. Conclusions Lignocellulosic waste after composting is a valuable and safe organic fertilizer.
\end{abstract}

Keywords Lignocellulosic composts $\cdot$ Chemical properties $\cdot$ Physical properties $\cdot$ Antagonistic fungi $\cdot$ Germination index

\section{Introduction}

Raw lignocellulosic waste is a rich source of carbon and energy and, therefore, has many applications. For example, biohydrogen is produced from many agricultural and food industrial waste containing starch and/or cellulose [1] and bioethanol from rice straw or wheat straw [2]. Biodiesel is produced from lignocellulosic biomass, while biomethane from wheat straw [3].

However, these are lignocellulosic composts that are irreplaceable in plant production [4]. Composted or

Justyna Bohacz

justyna.bohacz@up.lublin.pl

1 Laboratory of Mycology, Department of Environmental Microbiology, Faculty of Agrobioengineering, University of Life Sciences in Lublin, 7 Leszczyńskiego Street, 20-069 Lublin, Poland co-composted lignocellulosic waste includes leaves, grass, rice straw, wheat straw, sawdust and wood shavings [5-12].

Composts produced on the basis of raw lignocellulose materials are the main source precursors of humus along with other microbiological biotransformation products. During composting, part of the organic matter is mineralized to products that are considered indicators of compost quality assessment, and part is converted to humic substances, structurally similar to those in present in the soil [13]. Mature composts introduced into the soil act multidirectionally, which involves plants and soil properties, including its phytosanitary status, which in turn affects the health of the soil and cultivated plants [14-16]. Kuhad et al. [4] reported that composts introduced into the soil improved physical, chemical and biological properties of soil, because they provided good water and air conditions, improved soil structure and reduced its erosion. Composts containing plant material as the $\mathrm{C}$ source and feather waste 
as a source of nitrogen are rarely described. Bohacz and Korniłłowicz-Kowalska [17] reported that they contained not only a valuable source of various forms of nitrogen and carbon, but above all sulfur and sulphates generated from the biodegradation of waste feathers, which distinguished them from other composts.

Therefore, biological, chemical and physical properties are taken into account when assessing compost utility value. Good biological properties of the final composting product are associated with the absence of potential human pathogens (PHPs) in the compost mass environment and the presence of microorganisms supporting plant pathogen control [18]. In the latter case, composts play the role of a natural fungicide that improves phytosanitary status of the soil [15]. The utility value of composts is also determined by physical parameters, such as the appearance, bulk density, total porosity, field water capacity or moisture. They are, according to Agnew and Leonard [19], indicators describing the conditions in the composted mass and, at the same time, an indicator of compost usefulness. Some physical properties related to moisture and aeration of composted mass, such as bulk density may indicate the aerobic or anaerobic direction of organic matter transformation, and hence the release of heat and biomass transformation, and therefore, microbial kinetics. Physical parameters of composts are also important in terms of marketing, i.e., transportation or haulage viewpoint [19].

Biodegradation of organic matter with the participation of specialized groups of microorganisms (nutritionally specialized and non-nutritionally specialized group of microorganisms) Bohacz [20] is accompanied by chemical changes. These parameters, e.g., $\mathrm{pH}$ or the $\mathrm{C}: \mathrm{N}$ ratio are directly related to microorganism activity. Some, such as cation exchange capacity (CEC), determine the availability of certain macro- and microelements. An excessive amount of heavy metal salts or phenols may have an adverse effect on the growth and development of plants, especially after application of these composts to the soil [21]. The solid fraction is usually taken into account when evaluating compost utility value. In contrast, there are few studies that assessed the aqueous fraction of composts, popularly called "compost tea". Shrestha et al. [22] reported that this fraction is a source of nutrients and can be used both in soil and foliar plant feeding. Therefore, phytotests using seeds of selected plants, e.g. Lepidium sativum L. or Brasica parachinensis Bailey are one of the most important assays in the assessment of both water extracts and solid fractions of composts [10, 23, 24]. Plant reaction is not only a response to the chemical composition of the solid and aqueous compost fractions, but also to the presence of microorganisms in these fractions. Biological activity of composts is the result of the activity of many different groups of saprophytic microorganisms, often called beneficial, antagonistic or biocontrol factors, which inhibit or completely prevent the development of the pathogen, stopping plant disease development [18].

The aim of this study was to evaluate the utility value of lignocellulosic composts that also contained chicken feathers, based on the rarely described physical properties of composts, and the content of macronutrients, micronutrients and heavy metals in the solid and water fraction in relation to the influence on growth and germination of the test plant. The biological activity of the investigated composts was also analyzed by assessing their phytosanitary potential based on the rarely described ratio of potentially phytopathogenic to antagonistic fungi. Moreover, tests for pathogenic bacteria and fecal egg parasites were also carried out due to the addition of animal waste (chicken feathers) and requirements concerning the quality and sanitary safety of composts.

\section{Materials and Methods}

The experimental material consisted of composts containing lignocellulosic waste prepared in two variants, each with a ratio of $\mathrm{C} / \mathrm{N}=25$. The first composting variant (compost I, PGSF) contained $42.86 \%$ pine bark, $34.28 \%$ grass, $20.00 \%$ sawdust and $2.86 \%$ broiler chicken feathers. The second composting variant (compost II, PSSF) contained 25.54\% pine bark, $10.63 \%$ wheat straw, $51.07 \%$ sawdust and $12.76 \%$ of broiler chicken feathers. The origin of raw materials used for composting, $\mathrm{C}$ and $\mathrm{N}$ contents and composting conditions were described in the study of Bohacz [20].

\section{Chemical Properties of Solid Compost Fractions}

Periodical chemical analyses of compost solid fractions carried out after $18 \mathrm{~h}$ (time point 0 ), 14 and 30 weeks included dry matter determination (DM) by weighing at $105{ }^{\circ} \mathrm{C}$, $\mathrm{N}$-total by the Dumas method and organic carbon after $18 \mathrm{~h}$ and 30 weeks of composting (Corg.) by the Alten method. Samples for determination of macro- and microelements and heavy metals were mineralized in aqua regia and then the following fractions were determined: $\mathrm{P}\left(\mathrm{P}_{2} \mathrm{O}_{5}\right)$-a spectrophotometric method using a flow autoanalyzer; $\mathrm{Ca}$ and $\mathrm{Mg}$ by atomic absorption spectrometry (AAS); K was determined by atomic emission spectrometry; S-total by plasma emission spectrometry (ICP); and microelements and heavy metals ( $\mathrm{Cd}, \mathrm{Cr}, \mathrm{Cu}, \mathrm{Fe}, \mathrm{Mn}, \mathrm{Ni}, \mathrm{Pb}, \mathrm{Zn}$ ) by AAS.

The analyses were performed at the Central Laboratory of Chemical Analyzes IUNG Pulawy, Poland. Additionally, after composting was completed, the sum of alkaline cations were determined using the Kappen method and the sorption capacity of composts (CEC) was calculated from the total hydrolytic acidity values and the sum of alkaline cations. After the completion of the composting process, the $E_{4} / E_{6}$ value was also determined, i.e., the ratio of absorbance at 
465 and $665 \mathrm{~nm}$ for humic acids, as described in the previous work of Bohacz [25]. The $\mathrm{C} / \mathrm{N}$ ratio in both composts was calculated at the end of the composting period, i.e., at month 7 .

\section{Physical Properties of Composts}

The physical properties of composts included determination of field water capacity, bulk density, total porosity, and ash content in dry matter [26]. The analysis was performed at the Institute of Soil Science, Engineering and Environment Shaping, University of Life Sciences, Lublin, Poland.

\section{Preparation of Water Extracts for Chemical Assays}

The water compost extracts for chemical analyses were prepared from $100 \mathrm{~g}$ of a representative compost sample collected from the surface and the middle compost layers in individual experimental time points, i.e., after mixing the materials used for composting (time point 0 ) and after 14 and 30 weeks. The averaged sample was suspended in $500 \mathrm{~mL}$ distilled water and shaken for $1 \mathrm{~h}$ on a rotary shaker; filtered and distilled water was added to a final volume of $1000 \mathrm{~mL}$.

\section{Chemical Analyses of Compost Water Extracts}

Chemical analyses of water extracts from composts included determination of $\mathrm{N}$ by flow spectrometry after mineralization of compost samples with concentrated sulfuric acid and an admixture of $30 \%$ solution of $\mathrm{H}_{2} \mathrm{O}_{2}+\mathrm{Fe}$, and $\mathrm{P}$ after mineralization in aqua regia; $\mathrm{Mg}$ and $\mathrm{Ca}$ were determined after mineralization in aqua regia using AAS; $\mathrm{K}$ was determined using atomic emission spectrometry and S-total by plasma emission spectrometry (ICP). Trace elements and heavy metals, i.e., $\mathrm{Cu}, \mathrm{Cr}, \mathrm{Cd}, \mathrm{Ni}, \mathrm{Pb}$ were determined by plasma emission spectrometry after sample mineralization in aqua regia and Fe, Mn and $\mathrm{Zn}$ by AAS.

All the above-mentioned chemical analyses in composts and water composts extracts were carried out in the Main Chemical Laboratory, Institute of Soil Science and Plant Cultivation, Puławy, Poland.

This work also presented data on the dynamics of N-total, $\mathrm{N}-\mathrm{NH}_{4}, \mathrm{~N}-\mathrm{NO}_{3}$ and $\mathrm{S}-\mathrm{SO}_{4}$ content changes in the water extracts for the purpose of assessing compost phytotoxicity that they have not been published yet.

\section{Effect of Composts on Seed Germination and Root Growth of Lepidium sativum $\mathrm{L}$.}

Composts phytotoxicity was analyzed after the composting process was completed. The research was carried out according to the Wong method [24] based on determining the percentage of germinated seeds using $L$. sativum $\mathrm{L}$. seeds instead of Brassica parachinensis Bailey seeds.

According to Masciandaro et al. [27], cress seeds are used for toxicity tests due to rapid growth as well as high sensitivity to toxic metabolites. Five seeds were placed on a filter paper saturated with water extracts from individual composts in the following concentrations: 1, 2, 5, 10 and $15 \%$. The experiment was performed on Petri dishes ( $\varnothing$ $90 \mathrm{~mm}$ ) with $7 \mathrm{~mL}$ of the appropriate concentration of compost extract. The control sample, instead of water compost extract, contained distilled water. There were six replicates. According to Tiquia et al. [28], the use of different number of seeds depends not only on the size of the seeds, but also on the space intended for germination and root elongation. The seeds were placed in a growth chamber at $25{ }^{\circ} \mathrm{C}$ with $16 \mathrm{~h}$ light and $8 \mathrm{~h}$ dark cycle, as described by Wong [24]. Germination energy was measured after 4 days of incubation in relation to 100 placed seeds. The root elongation was measured every day for a period of 10 days. The germination index (GI) awas calculated according to Tam and Tiquia [29]. Tiquia et al. [28] described germination index as a factor of the relative seed germination and relative root elongation.

\section{Sanitary and Phytosanitary Compost Analyses}

The compost sanitary analysis included the detection and determination of Salmonella rods and the detection of parasitic helminth eggs of Ascaris lumbricoides and Trichuris trichiura due to the presence animal-derived components (chicken feathers). The determination was performed according to the standard and documented procedure in the Laboratory of the Provincial Environmental Protection Inspectorate, Lublin, Poland. These assays were carried out after composting was completed.

The phytosanitary analysis of composts consisted in determining the ratio of the frequency of potentially antagonistic to phytopathogenic fungi at the beginning (time point 0 ) and at the end of composting (30 weeks). The plate dilution method was used for fungal isolation on the substrate of Martin [30]. The generic and species composition of fungi was determined with particular regard to to the genus Fusarium. For this purpose, all colonies that grew at the beginning and end of composting were inoculated onto agar slants (PDA medium) from three plate replicates, for each compost I and II. Genus 
and species identification of fungi was conducted on the basis of micro- and macromorphological features based on taxonomic studies of Domsch et al. [31], Barnett [32] and van Oorscht [33].

\section{Statistical Evaluation}

Statistical analyses of the data were conducted using STATISTICA 12 software. One-way analysis of variance (ANOVA) and multiple comparison Fisher's test were performed to compare statistically homogeneous groups for the tested means in individual weeks. PCA was used to demonstrate the effect of water-soluble compounds on GI of $L$. sativum.

\section{Results and Discussion}

The costs of composting of lignocellulosic waste with chicken feather waste are important due to the application value of composts. According to Lashermes et al. [34], the composting process itself is economically viable, because it does not generate waste biomass and contributes to the circulation of elements in nature. These authors believe that the occurrence of successive biothermal phases and transformation of other composting parameters on a micro-scale should be the same as on a macro-scale. Miniaturization of the composting process is required especially when hazardous materials are suspected, as it allows to develop proper control and efficiency of the process.

\section{Dry Matter, C Organic and C/N in the Solid Fraction of Lignocellulosic Composts}

Dry matter content in individual compost variants was at a similar level and was lower than the dry mass of organic material before composting (time point 0 ). The level of organic $\mathrm{C}$ after the end of the composting process decreased due to the mineralization and $\mathrm{CO}_{2}$ emission (Table 1).
Bernal et al. [35] and Goyal et al. [36] stated that the decline of organic matter and/or C org. concentrations in composts proved the degradation of organic materials during composting. According to our own research, the rate of organic $\mathrm{C}$ mineralization in compost I (PGSF), enriched with the addition of an easily available organic matter fraction (grass), was faster than in compost II (PSSF), containing mainly less easily available organic matter fractions. This manifested as a decrease in organic C content by 31.96 and $11.32 \%$, respectively (Table 1). The slower reduction of C-organic in compost II resulted from more than 2 times higher sawdust content, including lignin. According to Goyal et al. [36], the higher content of carbon compounds, such as lignin in composted mass contributes to the slow decline in organic $\mathrm{C}$ levels during composting.

Lasaridi et al. [37] reported that the $\mathrm{C} / \mathrm{N}$ ratio is considered to be an older indicator of stability and maturity of compost, however it is still used. W badanych kompostach the $\mathrm{C} / \mathrm{N}$ ratio in compost I and II in the 7th month of composting decreased from 25 to 14.57 and 20.34, respectively. Based on this parameter, compost I can be considered ready for use after a 30-week composting period. According to the literature [38], the $\mathrm{C} / \mathrm{N}$ ratio in composts is satisfactory when it is around 20 at the initial $\mathrm{C} / \mathrm{N}$ ratio between 25 and 30 . Therefore, compost II can be considered as initially mature, because the $\mathrm{C} / \mathrm{N}$ ratio decreased by $20 \%$. Mathur et al. [21] and Brewer and Sulliwan [39] reported that C/N between 12 and 20 indicated maturity of the composted mass, although some authors consider compost to be mature when $\mathrm{C} / \mathrm{N}$ is below 12 [40] or 15 [41].

\section{Humification Indicators}

The degree of "maturation" of specific humus compounds reflects cation exchange capacity (CEC) [42, 43]. GavilanesTerán et al. [42], in a study on manure composting, showed correlations between CEC values and parameters determining the degree of humification. CEC was relatively high in the studied lignocellulosic composts, PGSF (compost I) and
Table 1 Selected chemical properties of lignocellulosic composts

\begin{tabular}{|c|c|c|c|c|c|c|}
\hline \multirow[t]{3}{*}{ Chemical properties } & \multirow{2}{*}{\multicolumn{3}{|c|}{$\frac{\text { Experimental time point (weeks) }}{\text { Compost I (PGSF) }}$}} & \multirow{2}{*}{\multicolumn{3}{|c|}{$\frac{\text { Experimental time point (weeks) }}{\text { Compost II (PSSF) }}$}} \\
\hline & & & & & & \\
\hline & 0 & 14 & 30 & 0 & 14 & 30 \\
\hline \multicolumn{7}{|l|}{ Solid fraction of composts } \\
\hline Dry weight (\%) & 61.18 & 25.66 & 23.56 & 60.10 & 29.44 & 20.40 \\
\hline $\mathrm{C}$ org. (g kg ${ }^{-1}$ d.w. $)$ & 458.60 & - & 312.00 & 447.50 & - & 396.80 \\
\hline $\begin{array}{l}\text { The sum of alkaline cations } \\
\mathrm{Ca}+\mathrm{Mg}+\mathrm{K}+\mathrm{Na} \\
\mathrm{cmol}(+) \mathrm{kg}^{-1}\end{array}$ & - & - & 30 & - & - & 60.4 \\
\hline $\begin{array}{l}\mathrm{CEC}_{8,1} \\
\mathrm{cmol}^{(+)} \mathrm{kg}^{-1}\end{array}$ & - & - & 75.45 & - & - & 106.15 \\
\hline
\end{tabular}


PSSF (compost II), which was conditioned by high organic matter content. It was shown that the obtained CEC values were within $75.45-106.15 \mathrm{cmol}(+) \mathrm{kg}^{-1}$ (which is equivalent to compost meq/100 g) and were lower than humus CEC (Table 1). Mathur et al. [21] reported that humus CEC was about $150 \mathrm{meq} / 100 \mathrm{~g}$. However, the obtained CEC values of the composts tested were much higher than those proposed by Iglesias-Jiménez and Pérez-García [44] as compost maturity indicators (i.e., between 60 and $67 \mathrm{meq} / 100 \mathrm{~g}$ ). Gao et al. [10] reported that the CEC value increased even to approx. $200 \mathrm{cmol} \mathrm{kg}^{-1}$ on day 62 of chicken manure and sawdust composting, which indicated accumulation of lignin-derived products and carboxyl and/or phenolic hydroxyl groups. However, according to some authors [35], CEC cannot be considered as an indicator of the maturity of composts containing different wastes. Mathur et al. [21] pointed out that even the same humic substances can change at the same CEC values, partly as a result of blocking of their exchange sites by complexing ions, such as $\mathrm{Cu}, \mathrm{Fe}$ and $\mathrm{Al}$ or as a result of interaction with amorphous $\mathrm{Fe}$ and $\mathrm{Al}$ compounds. Therefore, not only CEC, but also the sum of basic cations was determined in this work, considering the potential possibilities of composts for nutrient storage. The tests showed (Table 1) that the sum of alkaline cations: $\mathrm{Ca}^{2+}$, $\mathrm{Mg}^{2+}, \mathrm{K}^{+}, \mathrm{Na}^{+}$reached slightly higher values than the optimal values of the sum of exchangeable cations for soils [45].

\section{Physical Properties of Composts}

The appearance and compost temperature, which should be close to the ambient temperature, are the simplest and most easily observable physical parameters describing compost maturity [21]. Compost I (PGSF) was especially characterized by the gradual darkening of composted mass, which could be related to humification of organic matter and reduction of its volume. Several biothermal phases were selected during the composting process of lignocellulosic waste that differed in temperature [20]. The temperature of the composted mass in the 7th month of composting was close to the ambient temperature in compost I (PGSF) and compost II (PSSF) and was $24^{\circ} \mathrm{C}$. Vukobratović et al. [46] reported that physical properties depend on type of organic waste like type of manure. The analysis of the physical properties of the obtained composts indicated their high total porosity, which is essential in providing air access. Agnew and Leonard [19] reported that the optimal density for aerobic decomposition was in the range of $85-90 \%$. The porosity values in the test composts were in the range of values for peat soils (61-92 in weight percentage) [45]. Compost I had lower porosity, compost II slightly higher (Table 2). Haynes and Zhou [47] obtained similar to ours porosity values in compost from municipal green waste and municipal green waste plus green garden waste and cattle manure. According to Hannon and Mason [48], bulk density is a useful indicator of free air spaces potential in the composting pile. Bulk density of the obtained composts was significantly lower than in composts from municipal green waste presented in the work of Haynes and Zhou [47] and was at a level similar to the values recorded in peat soils [46]. These values were much lower than in mineral soils, which are characterized by high density of the solid fraction [45]. Such properties also cause good aeration of compost and provide a light product, which is important in terms of horticultural production. The obtained composts were characterized by a low field water capacity (FC) (Table 2). The ash content in the dry mass of the composts tested was $12.45 \%$ in compost II and $15.62 \%$ in compost I (Table 2), which would indicate its relatively low mineralization. A study of Wang et al. [49] showed that a clear increase in the ash content in the dry matter occured only when organic matter was significantly reduced during lignocellulosic waste composting from dairy manure and pig manure. It is known, however, that composts are a source of humus and its biogenesis continues after introducing compost into the soil.

\section{Macroelement Contents in Compost Solid Fractions and Water Extracts}

It was shown that the content of $\mathrm{N}, \mathrm{P}, \mathrm{K}$ in composts I (PGSF) and II (PSSF) was at the similar or higher level than the quality requirements for organic fertilizers produced from composting, as published in the article of the Ministry of the Environment [50]. The Ministry of the Environment in Poland recommends the following element values of the
Table 2 Physical properties of composts prepared from lignocellulosic wastes

\begin{tabular}{|c|c|c|c|c|c|c|}
\hline \multirow[t]{3}{*}{ Physical properties } & \multicolumn{3}{|c|}{ Experimental time point (weeks) } & \multicolumn{3}{|c|}{$\begin{array}{l}\text { Experimental time point } \\
\text { (weeks) }\end{array}$} \\
\hline & \multicolumn{3}{|c|}{ Compost I (PGSF) } & \multicolumn{3}{|c|}{ Compost II (PSSF) } \\
\hline & 0 & 14 & 30 & 0 & 14 & 30 \\
\hline Field water capacity ( $\%$ by weight) & - & - & 50.4 & - & - & 49.5 \\
\hline Bulk density $\left(\mathrm{Mg} \mathrm{m}^{-3}\right)$ & - & - & 0.166 & - & - & 0.139 \\
\hline Total porosity (\%) & - & - & 85.0 & - & - & 86.3 \\
\hline Ash content in dry matter (\%) & - & - & 15.62 & - & - & 12.45 \\
\hline
\end{tabular}


fertilizer mass: the content of nitrogen $(\mathrm{N}) \geq 0.3 \%$, phosphorus $\left(\mathrm{P}_{2} \mathrm{O}_{5}\right) \geq 0.2 \%$ and potassium $\left(\mathrm{K}_{2} \mathrm{O}_{5}\right) \geq 0.2 \%$. The content of the analyzed macroelements (N, P, K, S, Ca, and $\mathrm{Mg}$ ) was increased in the solid fraction of compost I (PGSF) after the end of composting. However, it was lower than in the 14th week of composting (Table 3). The content of these macroelements in the compost II variant (PSSF) was the highest at the end of the composting period except for sulfur. In the obtained composts, nitrogen concentrations were at a similar level to those in composts containing vegetable waste with sawdust and laying hen manure [42] and to concentrations in compost containing tobacco-dust-waste with wheat straw and ground bark of coniferous tree [51]. The obtained concentrations of $\mathrm{N}<30 \mathrm{~g} \mathrm{~kg}^{-1}$ in lignocellulosic composts were within the criteria provided in the EU Official Journal containing the ecological criteria for soil improvers and growing media [52] and guidelines given by the Ministry of the Environment in Poland [50]. Concentrations of the remaining macroelements in the solid fraction of composts were significantly lower than those described in the works of Gavilanes-Terán et al. [42] and Szwed and Bohacz [51]. However, in relation to the values provided in the article of the Ministry of the Environment in Poland [50], regarding requirements for the processes of composting, fermentation and mechanical-biological waste treatment from 2008, the content of potassium in compost I (PGSF) was 2-4 times higher (required dose weight $\% \geq 0.2$ ) and phosphorus was at a similar level (required dose weight $\% \geq 0.2$ ) (Table 3). The potassium content in compost II (PSSF) was at a minimum level and phosphorus was ten times lower compared to the data of the Minister of the Environment in Poland [41] (Table 3).

According to El-Gohary et al. [53], soluble P, K, Ca, Fe and $\mathrm{S}$ with humic acid can be quickly absorbed and assimilated by plants after applying compost to the soil or as foliar fertilizers. In the case of water extracts of composts investigated in this study, it was found that after 14 weeks of composting, only $\mathrm{P}$ and $\mathrm{K}$ in water extracts in compost I and $\mathrm{P}$ in compost II increased slightly compared to the initial phase (Table 3). A significant reduction in the concentration
Table 3 Macroelements in the solid fraction and in water extracts of lignocellulosic composts

\begin{tabular}{|c|c|c|c|c|c|c|}
\hline \multirow[t]{3}{*}{ Parameters } & \multicolumn{3}{|c|}{ Time of composting (weeks) } & \multicolumn{3}{|c|}{ Time of composting (weeks) } \\
\hline & \multicolumn{3}{|c|}{ Compost I (PGSF) } & \multicolumn{3}{|c|}{ Compost II (PSSF) } \\
\hline & 0 & 14 & 30 & 0 & 14 & 30 \\
\hline \multicolumn{7}{|c|}{ Solid fraction of composts } \\
\hline $\mathrm{N}$ ( $\mathrm{g} \mathrm{kg}^{-1}$ d.w. $)$ & $\begin{array}{l}14.2^{\mathrm{a}} \\
\pm 0.001\end{array}$ & $\begin{array}{l}23.5^{\mathrm{c}} \\
\pm 0.00\end{array}$ & $\begin{array}{l}21.4^{\mathrm{b}} \\
\pm 0.001\end{array}$ & $\begin{array}{l}10.3^{\mathrm{a}} \\
\pm 0.00\end{array}$ & $\begin{array}{l}18.2^{\mathrm{c}} \\
\pm 0.00\end{array}$ & $\begin{array}{l}19.5^{\mathrm{b}} \\
\pm 0.00\end{array}$ \\
\hline $\mathrm{P}\left(\mathrm{g} \mathrm{kg}^{-1}\right.$ d.w. $)$ & $\begin{array}{l}1.40^{\mathrm{a}} \\
\pm 0.00\end{array}$ & $\begin{array}{l}2.20^{c} \\
\pm 0.00\end{array}$ & $\begin{array}{l}1.90^{\mathrm{b}} \\
\pm 0.00\end{array}$ & $\begin{array}{l}0.39^{\mathrm{a}} \\
\pm 0.00\end{array}$ & $\begin{array}{l}0.49^{\mathrm{b}} \\
\pm 0.00\end{array}$ & $\begin{array}{l}0.55^{\mathrm{c}} \\
\pm 0.00\end{array}$ \\
\hline $\mathrm{K}\left(\mathrm{g} \mathrm{kg}^{-1}\right.$ d.w. $)$ & $\begin{array}{l}4.30^{\mathrm{a}} \\
\pm 0.03\end{array}$ & $\begin{array}{l}9,60^{c} \\
\pm 0.01\end{array}$ & $\begin{array}{l}8.40^{\mathrm{b}} \\
\pm 0.00\end{array}$ & $\begin{array}{l}1.60^{\mathrm{a}} \\
\pm 0.00\end{array}$ & $\begin{array}{l}2.00^{\mathrm{b}} \\
\pm 0.00\end{array}$ & $\begin{array}{l}3.10^{\mathrm{c}} \\
\pm 0.00\end{array}$ \\
\hline $\mathrm{S}$ ( $\mathrm{g} \mathrm{kg}^{-1}$ d.w. $)$ & $\begin{array}{l}1,477^{\mathrm{a}} \\
\pm 0.04\end{array}$ & $\begin{array}{l}3,074^{\mathrm{c}} \\
\pm 0.04\end{array}$ & $\begin{array}{l}2,470^{\mathrm{b}} \\
\pm 0.08\end{array}$ & $\begin{array}{l}1,876^{\mathrm{a}} \\
\pm 0.04\end{array}$ & $\begin{array}{l}3,686^{\mathrm{c}} \\
\pm 0.07\end{array}$ & $\begin{array}{l}3,263^{\mathrm{b}} \\
\pm 0.13\end{array}$ \\
\hline $\mathrm{Ca}\left(\mathrm{g} \mathrm{kg}^{-1}\right.$ d.w. $)$ & $\begin{array}{l}8.20^{\mathrm{a}} \\
\pm 0.07\end{array}$ & $\begin{array}{l}13.90^{c} \\
\pm 0.01\end{array}$ & $\begin{array}{l}13.10^{\mathrm{b}} \\
\pm 0.01\end{array}$ & $\begin{array}{l}3.80^{\mathrm{a}} \\
\pm 0.00\end{array}$ & $\begin{array}{l}4.40^{\mathrm{b}} \\
\pm 0.00\end{array}$ & $\begin{array}{l}8.90^{c} \\
\pm 0.00\end{array}$ \\
\hline $\operatorname{Mg}\left(\mathrm{g} \mathrm{kg}^{-1}\right.$ d.w. $)$ & $\begin{array}{l}2.1^{\mathrm{a}} \\
\pm 0.02\end{array}$ & $\begin{array}{l}3.2^{\mathrm{c}} \\
\pm 0.00\end{array}$ & $\begin{array}{l}2.9^{\mathrm{b}} \\
\pm 0.00\end{array}$ & $\begin{array}{l}0.47^{\mathrm{a}} \\
\pm 0.00\end{array}$ & $\begin{array}{l}0.6^{\mathrm{b}} \\
\pm 0.00\end{array}$ & $\begin{array}{l}0.83^{\mathrm{c}} \\
\pm 0.00\end{array}$ \\
\hline \multicolumn{7}{|c|}{ Water extract of composts } \\
\hline $\mathrm{N}\left(\mathrm{mg} \mathrm{kg}^{-1}\right)$ & $\begin{array}{l}96.0^{c} \\
\pm 0.07\end{array}$ & $\begin{array}{l}89.5^{\mathrm{b}} \\
\pm 0.28\end{array}$ & $\begin{array}{l}26.0^{\mathrm{a}} \\
\pm 0.11\end{array}$ & $\begin{array}{l}51.5^{\mathrm{c}} \\
\pm 0.03\end{array}$ & $\begin{array}{l}28.0^{\mathrm{b}} \\
\pm 0.3\end{array}$ & $\begin{array}{l}27.5^{\mathrm{a}} \\
\pm 0.37\end{array}$ \\
\hline $\mathrm{P}\left(\mathrm{mg} \mathrm{kg}^{-1}\right)$ & $\begin{array}{l}56.70^{\mathrm{a}} \\
\pm 3.55\end{array}$ & $\begin{array}{l}65.40^{\mathrm{a}} \\
\pm 4.11\end{array}$ & $\begin{array}{l}61.00^{\mathrm{a}} \\
\pm 3.55\end{array}$ & $\begin{array}{l}37.50^{\mathrm{ab}} \\
\pm 1.60\end{array}$ & $\begin{array}{l}41.00^{\mathrm{b}} \\
\pm 2.84\end{array}$ & $\begin{array}{l}34.90^{\mathrm{a}} \\
\pm 2.88\end{array}$ \\
\hline $\mathrm{K}\left(\mathrm{mg} \mathrm{kg}^{-1}\right)$ & $\begin{array}{l}182.80^{\mathrm{b}} \\
\pm 12.39\end{array}$ & $\begin{array}{l}227.30^{c} \\
\pm 15.55\end{array}$ & $\begin{array}{l}107.40^{\mathrm{a}} \\
\pm 0.00\end{array}$ & $\begin{array}{l}44.80^{c} \\
\pm 1.68\end{array}$ & $\begin{array}{l}32.20^{\mathrm{b}} \\
\pm 1.02\end{array}$ & $\begin{array}{l}17.70^{\mathrm{a}} \\
\pm 0.04\end{array}$ \\
\hline $\mathrm{S}\left(\mathrm{mg} \mathrm{kg}^{-1}\right)$ & $\begin{array}{l}19.7^{\mathrm{c}} \\
\pm 0.21\end{array}$ & $\begin{array}{l}15.5^{\mathrm{b}} \\
\pm 1.68\end{array}$ & $\begin{array}{l}9.12^{\mathrm{a}} \\
\pm 1.08\end{array}$ & $\begin{array}{l}12.3^{\mathrm{b}} \\
\pm 1.08\end{array}$ & $\begin{array}{l}4.43^{\mathrm{a}} \\
\pm 0.68\end{array}$ & $\begin{array}{l}4.86^{\mathrm{a}} \\
\pm 0.50\end{array}$ \\
\hline $\mathrm{Ca}\left(\mathrm{mg} \mathrm{kg}^{-1}\right)$ & $\begin{array}{l}113.00^{\mathrm{b}} \\
\pm 1.06\end{array}$ & $\begin{array}{l}109.90^{\mathrm{a}} \\
\pm 0.22\end{array}$ & $\begin{array}{l}109.90^{\mathrm{a}} \\
\pm 1.91\end{array}$ & $\begin{array}{l}50.3^{\mathrm{c}} \\
\pm 0.56\end{array}$ & $\begin{array}{l}37,80^{\mathrm{b}} \\
\pm 0.52\end{array}$ & $\begin{array}{l}32.80^{\mathrm{a}} \\
\pm 0.34\end{array}$ \\
\hline $\operatorname{Mg}\left(\mathrm{mg} \mathrm{kg}^{-1}\right)$ & $\begin{array}{l}39.60^{\mathrm{b}} \\
\pm 0.20\end{array}$ & $\begin{array}{l}27.70^{\mathrm{a}} \\
\pm 1.01\end{array}$ & $\begin{array}{l}27.20^{\mathrm{a}} \\
\pm 0.69\end{array}$ & $\begin{array}{l}8.38^{c} \\
\pm 0.115\end{array}$ & $\begin{array}{l}4.70^{\mathrm{b}} \\
\pm 0.04\end{array}$ & $\begin{array}{l}4.18^{\mathrm{a}} \\
\pm 0.06\end{array}$ \\
\hline
\end{tabular}

Small letters (a, b, c) designate homogenous groups; means marked with the same letter [e.g., a and a do not differ significantly $(\alpha=0.05)$ ]. Means marked with different letters (e.g., a and b) differ significantly $(\alpha=0.05)$ 
of all tested macroelements was noted in the final stage of composting (30 weeks), i.e., N, P, K, Ca and Mg, except for $\mathrm{P}$ concentration in compost I (Table 3 ), and in water extracts these values were lower (without converting to dry mass of compost) than those published in the work by Szewczuk and Sugier [54] for multicomponent foliar fertilizers.

\section{Microelements and Heavy Metals in the Solid Fraction and Water Extract of Composts}

The compost used for fertilizing purposes should contain macro- and microelements necessary for plants. Especially composts composed of municipal waste and those with animal waste can contain heavy metals. Many heavy metals remain in the end product, which affects the application value of these composts and consequently exert the impact on plants and soil. According to Ko et al. [55], generally, the amount of organic impurities as phenols or ammonia decreases during composting. Inhibition of germination and plant growth is caused not only by organic substances, but also by factors such as salinity, heavy metals, compaction, moisture or aeration [56]. El-Nagerabi et al. [57] reported that composts significantly reduced the transport of heavy metals to plants due to complex formation. The content of microelements and heavy metals $(\mathrm{Cd}, \mathrm{Cr}, \mathrm{Cu}, \mathrm{Fe}, \mathrm{Mn}, \mathrm{Ni}$, $\mathrm{Pb}$, and $\mathrm{Zn}$ ) in the tested lignocellulosic composts after
Table 4 Microelements and heavy metals in the solid fraction of composts and in the water extract of lignocellulosic composts

\begin{tabular}{|c|c|c|c|c|c|c|}
\hline \multirow[t]{3}{*}{ Parameters } & \multicolumn{3}{|c|}{ Time of composting (weeks) } & \multicolumn{3}{|c|}{ Time of composting (weeks) } \\
\hline & \multicolumn{3}{|c|}{ Compost I (PGSF) } & \multicolumn{3}{|c|}{ Compost II (PSSF) } \\
\hline & 0 & 14 & 30 & 0 & 14 & 30 \\
\hline \multicolumn{7}{|c|}{ Solid fraction of composts } \\
\hline $\mathrm{Cd}\left(\mathrm{mg} \mathrm{kg}^{-1}\right.$ d.w.) & $\begin{array}{l}0.30^{\mathrm{b}} \\
\pm 0.02\end{array}$ & $\begin{array}{l}0.69^{\mathrm{a}} \\
\pm 0.01\end{array}$ & $\begin{array}{l}0.72^{\mathrm{a}} \\
\pm 0.05\end{array}$ & $\begin{array}{l}0.3^{\mathrm{a}} \\
\pm 0.00\end{array}$ & $\begin{array}{l}0.38^{\mathrm{b}} \\
\pm 0.01\end{array}$ & $\begin{array}{l}0.81^{\mathrm{c}} \\
\pm 0.01\end{array}$ \\
\hline $\mathrm{Cr}$ (mg kg ${ }^{-1}$ d.w. $)$ & $\begin{array}{l}2.05^{\mathrm{a}} \\
\pm 0.00\end{array}$ & $\begin{array}{l}16.10^{c} \\
\pm 0.35\end{array}$ & $\begin{array}{l}3.31^{\mathrm{b}} \\
\pm 0.00\end{array}$ & $\begin{array}{l}2.66^{\mathrm{a}} \\
\pm 0.09\end{array}$ & $\begin{array}{l}3.38^{\mathrm{b}} \\
\pm 0.09\end{array}$ & $\begin{array}{l}3.87^{\mathrm{c}} \\
\pm 0.10\end{array}$ \\
\hline $\mathrm{Cu}\left(\mathrm{mg} \mathrm{kg}^{-1}\right.$ d.w. $)$ & $\begin{array}{l}5.03^{\mathrm{a}} \\
\pm 0.26\end{array}$ & $\begin{array}{l}9.41^{\mathrm{c}} \\
\pm 0.17\end{array}$ & $\begin{array}{l}7.95^{\mathrm{b}} \\
\pm 0.19\end{array}$ & $\begin{array}{l}2.96^{\mathrm{a}} \\
\pm 0.10\end{array}$ & $\begin{array}{l}3.76^{\mathrm{b}} \\
\pm 0.13\end{array}$ & $\begin{array}{l}4.92^{\mathrm{c}} \\
\pm 0.32\end{array}$ \\
\hline $\operatorname{Mn}\left(\mathrm{mg} \mathrm{kg}^{-1}\right.$ d.w.) & $\begin{array}{l}108.00^{\mathrm{a}} \\
\pm 4.55\end{array}$ & $\begin{array}{l}370.00^{c} \\
\pm 3.63\end{array}$ & $\begin{array}{l}237.00^{\mathrm{b}} \\
\pm 0.66\end{array}$ & $\begin{array}{l}154.00^{\mathrm{a}} \\
\pm 1.62\end{array}$ & $\begin{array}{l}203.00^{\mathrm{b}} \\
\pm 3.81\end{array}$ & $\begin{array}{l}156.00^{\mathrm{a}} \\
\pm 4.57\end{array}$ \\
\hline $\mathrm{Ni}\left(\mathrm{mg} \mathrm{kg}^{-1}\right.$ d.w.) & $\begin{array}{l}1.85^{\mathrm{a}} \\
\pm 0.00\end{array}$ & $\begin{array}{l}6.71^{\mathrm{c}} \\
\pm 0.00\end{array}$ & $\begin{array}{l}4.88^{\mathrm{b}} \\
\pm 0.37\end{array}$ & $\begin{array}{l}11.60^{\mathrm{a}} \\
\pm 0.33\end{array}$ & $\begin{array}{l}12.70^{\mathrm{a}} \\
\pm 1.93\end{array}$ & $\begin{array}{l}5.11^{\mathrm{b}} \\
\pm 0.14\end{array}$ \\
\hline $\mathrm{Pb}$ (mg kg${ }^{-1}$ d.w. $)$ & $\begin{array}{l}0.71^{\mathrm{a}} \\
\pm 0.16\end{array}$ & $\begin{array}{l}1.24^{\mathrm{b}} \\
\pm 0.18\end{array}$ & $\begin{array}{l}2.20^{c} \\
\pm 0.09\end{array}$ & $\begin{array}{l}0.71^{\mathrm{a}} \\
\pm 0.16\end{array}$ & $\begin{array}{l}1.13^{\mathrm{b}} \\
\pm 0.16\end{array}$ & $\begin{array}{l}2.06^{\mathrm{c}} \\
\pm 0.16\end{array}$ \\
\hline $\mathrm{Zn}\left(\mathrm{mg} \mathrm{kg}^{-1}\right.$ d.w. $)$ & $\begin{array}{l}37.50^{\mathrm{a}} \\
\pm 2.01\end{array}$ & $\begin{array}{l}82.00^{c} \\
\pm 0.54\end{array}$ & $\begin{array}{l}57.10^{\mathrm{b}} \\
\pm 0.39\end{array}$ & $\begin{array}{l}29.10^{\mathrm{a}} \\
\pm 1.14\end{array}$ & $\begin{array}{l}39.60^{\mathrm{b}} \\
\pm 0.56\end{array}$ & $\begin{array}{l}57.90^{c} \\
\pm 0.70\end{array}$ \\
\hline $\mathrm{Fe}\left(\mathrm{mg} \mathrm{kg}^{-1}\right.$ d.w. $)$ & $\begin{array}{l}358.00^{\mathrm{a}} \\
\pm 25.80\end{array}$ & $\begin{array}{l}794.00^{c} \\
\pm 7.14\end{array}$ & $\begin{array}{l}529.00^{\mathrm{b}} \\
\pm 2.49\end{array}$ & $\begin{array}{l}400.00^{\mathrm{a}} \\
\pm 16.56\end{array}$ & $\begin{array}{l}563.00^{\mathrm{b}} \\
\pm 16.98\end{array}$ & $\begin{array}{l}377.00^{\mathrm{a}} \\
\pm 5.79\end{array}$ \\
\hline \multicolumn{7}{|c|}{ Water extract of composts } \\
\hline $\mathrm{Cd}\left(\mathrm{mg} \mathrm{kg}^{-1}\right)$ & $\begin{array}{l}0.006^{\mathrm{b}} \\
\pm 0.00\end{array}$ & $\begin{array}{l}0.010^{\mathrm{a}} \\
\pm 0.00\end{array}$ & $\begin{array}{l}0.005^{\mathrm{a}} \\
\pm 0.00\end{array}$ & $\begin{array}{l}0.006^{\mathrm{b}} \\
\pm 0.00\end{array}$ & $\begin{array}{l}0.002^{\mathrm{a}} \\
\pm 0.00\end{array}$ & $\begin{array}{l}0.003^{\mathrm{a}} \\
\pm 0.00\end{array}$ \\
\hline $\mathrm{Cr}\left(\mathrm{mg} \mathrm{kg}^{-1}\right)$ & $\begin{array}{l}0.011^{\mathrm{a}} \\
\pm 0.00\end{array}$ & $\begin{array}{l}0.015^{\mathrm{a}} \\
\pm 0.00\end{array}$ & $\begin{array}{l}0.033^{\mathrm{a}} \\
\pm 0.02\end{array}$ & $\begin{array}{l}0.017^{\mathrm{b}} \\
\pm 0.00\end{array}$ & $\begin{array}{l}0.002^{\mathrm{a}} \\
\pm 0.00\end{array}$ & $\begin{array}{l}0.005^{\mathrm{a}} \\
\pm 0.00\end{array}$ \\
\hline $\mathrm{Cu}\left(\mathrm{mg} \cdot \mathrm{kg}^{-1}\right)$ & $\begin{array}{l}0.204^{\mathrm{a}} \\
\pm 0.04\end{array}$ & $\begin{array}{l}0.154^{\mathrm{a}} \\
\pm 0.04\end{array}$ & $\begin{array}{l}0.058^{\mathrm{b}} \\
\pm 0.00\end{array}$ & $\begin{array}{l}0.105^{\mathrm{b}} \\
\pm 0.02\end{array}$ & $\begin{array}{l}0.035^{\mathrm{a}} \\
\pm 0.01\end{array}$ & $\begin{array}{l}0.052^{\mathrm{a}} \\
\pm 0.02\end{array}$ \\
\hline $\operatorname{Mn}\left(\mathrm{mg} \mathrm{kg}^{-1}\right)$ & $\begin{array}{l}1.131^{\mathrm{a}} \\
\pm 0.06\end{array}$ & $\begin{array}{l}1.035^{\mathrm{a}} \\
\pm 0.07\end{array}$ & $\begin{array}{l}0.747^{\mathrm{b}} \\
\pm 0.03\end{array}$ & $\begin{array}{l}0.524^{c} \\
\pm 0.01\end{array}$ & $\begin{array}{l}0.365^{\mathrm{b}} \\
\pm 0.02\end{array}$ & $\begin{array}{l}0.052^{\mathrm{a}} \\
\pm 0.00\end{array}$ \\
\hline $\mathrm{Ni}\left(\mathrm{mg} \mathrm{kg}^{-1}\right)$ & $\begin{array}{l}0.015^{\mathrm{a}} \\
\pm 0.00\end{array}$ & $\begin{array}{l}0.025^{\mathrm{a}} \\
\pm 0.00\end{array}$ & $\begin{array}{l}0.020^{\mathrm{a}} \\
\pm 0.00\end{array}$ & $\begin{array}{l}0.022^{\mathrm{a}} \\
\pm 0.00\end{array}$ & $\begin{array}{l}0.011^{\mathrm{a}} \\
\pm 0.00\end{array}$ & $\begin{array}{l}0.020^{\mathrm{a}} \\
\pm 0.01\end{array}$ \\
\hline $\mathrm{Pb}\left(\mathrm{mg} \mathrm{kg}^{-1}\right)$ & $\begin{array}{l}0.076^{\mathrm{a}} \\
\pm 0.01\end{array}$ & $\begin{array}{l}0.192^{c} \\
\pm 0.008\end{array}$ & $\begin{array}{l}0.170^{\mathrm{b}} \\
\pm 0.00\end{array}$ & $\begin{array}{l}0.114^{\mathrm{b}} \\
\pm 0.00\end{array}$ & $\begin{array}{l}0.074^{\mathrm{c}} \\
\pm 0.00\end{array}$ & $\begin{array}{l}0.123^{\mathrm{a}} \\
\pm 0.01\end{array}$ \\
\hline $\mathrm{Zn}\left(\mathrm{mg} \mathrm{kg}^{-1}\right)$ & $\begin{array}{l}0.824^{\mathrm{a}} \\
\pm 0.10\end{array}$ & $\begin{array}{l}0.931^{\mathrm{a}} \\
\pm 0.16\end{array}$ & $\begin{array}{l}0.492^{\mathrm{b}} \\
\pm 0.03\end{array}$ & $\begin{array}{l}0.811^{\mathrm{b}} \\
\pm 0.01\end{array}$ & $\begin{array}{l}0.428^{\mathrm{a}} \\
\pm 0.10\end{array}$ & $\begin{array}{l}0.420^{\mathrm{a}} \\
\pm 0.00\end{array}$ \\
\hline $\mathrm{Fe}\left(\mathrm{mg} \mathrm{kg}^{-1}\right)$ & $\begin{array}{l}4.326^{\mathrm{b}} \\
\pm 0.23\end{array}$ & $\begin{array}{l}5.051^{\mathrm{a}} \\
\pm 0.26\end{array}$ & $\begin{array}{l}1.929^{\mathrm{a}} \\
\pm 0.46\end{array}$ & $\begin{array}{l}6.271^{\mathrm{a}} \\
\pm 0.16\end{array}$ & $\begin{array}{l}1.292^{\mathrm{a}} \\
\pm 0.13\end{array}$ & $\begin{array}{l}1.472^{\mathrm{b}} \\
\pm 0.04\end{array}$ \\
\hline
\end{tabular}

Small letters (a, b, c) designate homogenous groups; means marked with the same letter [e.g., a and a do not differ significantly $(\alpha=0.05)$ ]. Means marked with different letters (e.g., a and b) differ significantly $(\alpha=0.05)$ 
30 weeks of composting is presented in Table 4. It was found that the content of heavy metals and trace elements $(\mathrm{Cd}, \mathrm{Pb}$, $\mathrm{Cr}, \mathrm{Cu}, \mathrm{Mn}, \mathrm{Ni}$ and $\mathrm{Zn}$ ) was low, significantly lower than the permissible amounts of these elements in composts according to the Ministry of the Environment and the Department of Waste Management in Poland [50], with the exception of $\mathrm{Pb}$ in compost II (PSSF) in the 30th week of composting. The Ministry of the Environment in Poland allows the following maximum permissible heavy metal levels in composts used as organic fertilizers: $\mathrm{Ni}-60, \mathrm{Cr}-100, \mathrm{Zn}-, \mathrm{Cu}-$, $\mathrm{Pb}-140, \mathrm{Cd}-5$ and $\mathrm{Hg}-2 \mathrm{mg} \mathrm{kg}^{-1}$ d.w. The concentration of all microelements and heavy metals in compost I and II was increasing up to the 14 th week of composting. Ko et al. [55] reported that the reduction of the compost mass (by 40-50\%) was accompanied by an increase in the concentration of metal ions. A decrease in $\mathrm{Fe}, \mathrm{Mn}, \mathrm{Ni}$ was recorded from the middle of the composting period in both composts as well as $\mathrm{Cr}$ and $\mathrm{Zn}$ in compost I. A similar trend was noted by Selim et al. [58] during composting of different organic wastes. Authors explained $\mathrm{Cu}$ and $\mathrm{Zn}$ decrease during composting by the formation of metal-humus complexes, which made them biologically inaccessible.

Tiquia et al. [28] and Tiquia [59] reported that the content of heavy metals in the compost aqueous fraction was more important than total metal concentration and that waterextractable chemical properties of the compost material had a significant impact on seed germination. Our research showed that the concentration of micronutrients and heavy metals in water extracts of the composts was lower than in the solid fraction (Table 4). In addition, their concentrations in solid and aqueous compost fractions did not exceed the values recommended in the Official Journal of the European Union [52].

\section{Sanitary and Phytosanitary Compost Analyses}

The tested composts were characterized by the absence of intestinal bacteria and parasitic worms (A. lumbricoides and T. trichiura), pathogenic for humans and animals. This fact allows to believe that composts composed of lignocellulosic waste with the addition of chicken feathers are sanitary safe.

The lack of phytotoxic effects is one of the most important features in the assessment of composts as fertilizers [60], which is directly related to their maturity. Mature composts with stabilized organic matter are characterized by the lack or low concentration of substances that inhibit seed germination [21].

Phytotoxicity assessment of compost impact (30-weekold composts) was carried out based on the results of germination tests of L. sativum L. (fast-germinating seeds) in the presence of increasing concentrations (1-15\%) of compost water extracts. It was shown that increasing concentrations of water composts extracts did not significantly affect the energy of seed germination. The average percentage of germinated seeds in the presence of all doses was very high in both compost I and II after 4 days (89-99\% and $97-99 \%$, respectively).

The GI, which according to Tiquia et al. [28] and Zucconi et al. [18] is a sensitive indicator of compost toxicity, was determined to assess their phytotoxicity. Tiquia [12] reported that GI was strictly dependent on the compost soluble chemical compounds in water extracts. Raj et al. [61], however, reported that heavy metals, ammonia and other toxic low molecular weight compounds present in the composted mass could be the reason for low GI. GI values may also indicate compost maturity, especially those in which animal wastes were composted, as reported by Ko et al. [55]. According to these authors, mature compost containing animal waste had a GI > 110. However, considered root elongation as a more sensitive indicator than germination, and therefore, in their view, GI should be considered with great caution, as an indicator of compost maturity. The assessment of compost phytotoxicity also depends on the applied plant test and extraction rates [55].

We showed in our research that GI in the water compost extracts decreased after the first day of seed germination (Fig. 1). On the other hand, root elongation at the same time was higher, which proved the stimulation of root growth (Fig. 1). In the following days of seed germination, the increase in root and shoot elongation in water extracts from compost I was decreased and was lower than in the control sample. The stimulation of root elongation was noted for compost II, especially by 1, 2 and $5 \%$ water extracts. The highest increase in root length was recorded in the presence of $5 \%$ extract of compost II. In the case of compost I, the increase in length was the highest after treatment with a $1 \%$ solution of the compost extract compared to the control and the lowest with $15 \%$ solution (Fig. 1).

It was found that the germination index in compost I (PGSF) ranged from 70 to $195 \%$ and 95 to $195 \%$ in compost II (PSSF). These values in compost II increased with the time of incubation in all water solutions and in compost I decreased in 10 and $15 \%$ solutions. In the light of research by Cui et al. [62], who presented four degrees of compost phytotoxicity (grade I-IV), determined based on GI values, the composts tested were not phytotoxic because they belonged to grade I for which GI was $\leq 80$. Ros et al. [63] obtained high GI values when composting wood shavings with animal waste such as pig slurry. According to Said-Pullicino et al. [64], GI is inversely proportional to the composition and concentration of water-extractable organic matter and the high concentration of water-soluble toxic compounds, such as organic acids and phenolic compounds released during the decomposition of composted organic matter affected the germination capacity of plant seeds. 
Fig. 1 Root elongation (a, b) and GI (c, d) in different percentage of water extracts in compost I $(\mathbf{a}, \mathbf{c})$ and compost II $(\mathbf{b}, \mathbf{d})$

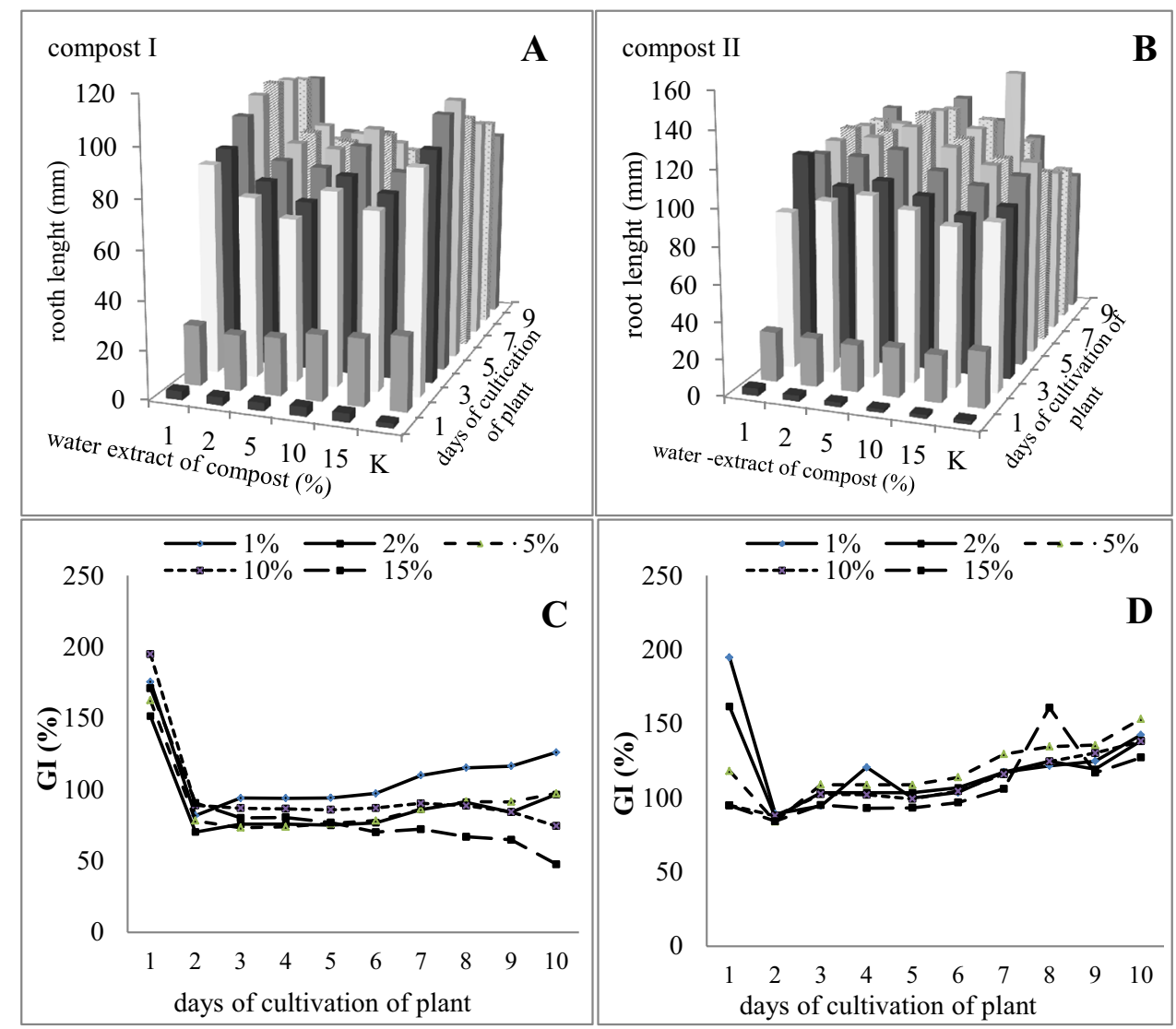

\section{General Estimation of Influence of Different Parameters on Germination Index}

The principal component analysis (PCA) was used to better assess the effect of micro- and macroelements and heavy metals contained in composts on GI and final product quality (Fig. 2). The variables included GI, organic matter (OM), $\mathrm{N}$-total, S-total, $\mathrm{SO}_{4}, \mathrm{NO}_{3}, \mathrm{NH}_{4}, \mathrm{P}, \mathrm{K}, \mathrm{Cd}, \mathrm{Cu}, \mathrm{Fe}, \mathrm{Mg}, \mathrm{Ca}$, $\mathrm{Zn}, \mathrm{Mn}, \mathrm{Ni}, \mathrm{Pb}, \mathrm{K}, \mathrm{P}$ and $\mathrm{Cr}$.

According to PCA, the two first factors explained $80.26 \%$ of total variation in compost I (PGSF). The first factor (PC1) explained $50.68 \%$ of the total variation and the most correlated variables were: $\mathrm{Cd}, \mathrm{Cu}, \mathrm{Fe}, \mathrm{Zn}, \mathrm{Mn}$, $\mathrm{K}, \mathrm{S}$-total, N-total and $\mathrm{N}-\mathrm{NH}_{4}{ }^{+}$. The second factor (PC2) explained $29.57 \%$ with $\mathrm{Mg}, \mathrm{Ca}, \mathrm{Pb}, \mathrm{P}, \mathrm{SO}_{4}, \mathrm{NO}_{3}$ and $\mathrm{OM}$. GI was not significantly correlated with any major component. According to Gramacki and Gramacki [65], the inclination angle of vectors relative to each other determines the correlations between the variables. In compost I, GI was significantly negatively affected by the majority of macro- and microelements and heavy metals, except for $\mathrm{Pb}, \mathrm{Cr}$ and $\mathrm{NO}_{3}$ ions.
Fig. 2 PCA of compost water extracts based on GI and macroand microelements, heavy metals and mineral forms of nitrogen and sulfur and $\mathrm{OM}$
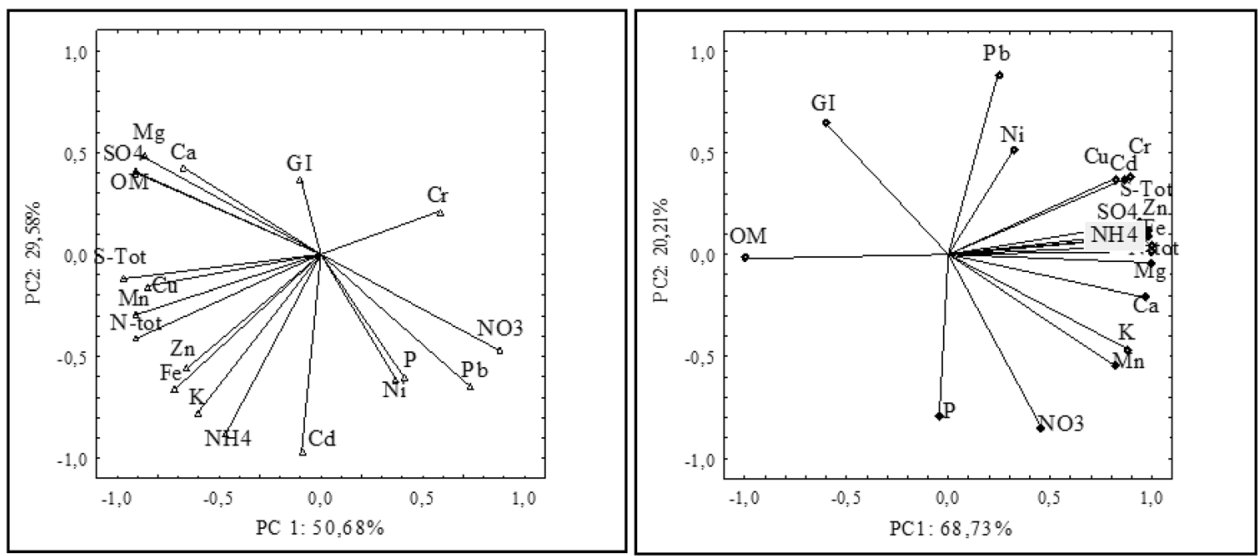
In compost II (PSFS), PC1 and PC2 explained 88.93\% of total variance (TV\%). The first factor explained $68.72 \%$ and was conditioned by $\mathrm{Cd}, \mathrm{Cu}, \mathrm{Fe}, \mathrm{Mg}, \mathrm{Ca}, \mathrm{Zn}, \mathrm{Mn}, \mathrm{K}$, $\mathrm{Cr} \mathrm{S}$-total, $\mathrm{SO}_{4}, \mathrm{~N}$-total, $\mathrm{NH}_{4}$ and $\mathrm{OM}$. The second factor (PC2) was associated with $\mathrm{Pb}, \mathrm{P}, \mathrm{N}-\mathrm{NO}_{3}$ and GI. It means that based on this analysis it was shown that the cress root elongation and seed germination in compost II was significantly adversely affected by the vast majority of micro- and macroelements, except for Ni. OM significantly positively correlated with GI. Studies of Tam and Tiquia [29] and Tiquia [59] demonstrated that generally all microelements and heavy metals $(\mathrm{Cu}, \mathrm{Zn}, \mathrm{Mn})$ inhibited germination and root elongation of various tested plants. Wong [58] included $\mathrm{Cu}, \mathrm{Zn}, \mathrm{Mn}, \mathrm{Pb}, \mathrm{Fe}$ and $\mathrm{Ni}$ to phytotoxic heavy metals, however, Dąbrowska et al. [66] reported a stimulative effect of $\mathrm{Pb}$ on germination and plant growth. It was shown in the composts studied that GI increased when the ammonia level decreased, similarly as in commercial composts and refuse composts [24].

\section{Mutual Relations Between Populations of Potentially Phytopathogenic and Antagonistic Fungi}

The natural resistance to soil pathogens is one of the undoubted advantages of composts, especially composts made of coniferous bark. Studies of different authors [15, 60, 67] indicated that composted bark and composts containing bark or their water extracts inhibited soil-borne pathogens, such as Fusarium spp., Rhizoctonia solani, Sclerotinia sclerotiorum and other that cause various plant diseases. This effect is primarily related to the presence of antagonistic microorganisms in these composts, in particular fungi such as: Trichoderma spp., Paecilomyces variotii, Penicillium janthinellium, Gliocladium virens and G. catenulatum [67]. Korniłłowicz [68] reported that fungi of the genus Trichoderma and Gliocladium showed antagonistic activity against many fungal pathogens.

The assessment of phytosanitary status of composts made of lignocellulosic waste was performed in this work on the basis of the isolate ratio of potentially antagonistic and phytopathogenic fungi, isolated on Martin's medium at the beginning (time point 0 ) and after the composting process (30 weeks) (Table 5).

Among the potentially phytopathogenic fungi isolated from composts, the following species were identified: Alternaria alternata, Fusarium solani and Fusarium oxysporum. Potentially antagonistic fungi were represented by the following species: Clonostachys rosea f. catenulata (former Gliocadium catenulatum), Penicillium sp. and Trichoderma viride. T. viride in compost I and II and Clonostachys rosea $f$. catenulata in compost II were among the most frequently occurring fungi. Pine bark could have been the source of these fungi, especially in compost I, because Ashraf et al. [69] reported that the genus Trichoderma commonly occurred on tree bark. A decrease in the frequency of Aspergillus fumigatus, considered as one of the most dangerous opportunistic human pathogens, was demonstrated during the composting process of lignocellulosic waste. According to Fischer et al. [70] and Krikštaponis et al. [71] and Lugauskas et al. [72], spores of this fungus can be abundantly present in the air of composting chamber, waste dumps and poultry farms. The intensive development of this fungus in composts is associated with a high risk of its penetration into the air, which poses a threat to human health, in particular in the form of the so-called lung aspergillosis. Such effect was obtained by Franceschini et al. [73]. These authors observed that the concentration of $A$. fumigatus increased during longer composting and aeration in composts consisting in different types of waste, such as green waste and municipal waste, animal manure and agrifood waste. Hence, the reduction of A. fumigatus population density in composts obtained in this work indicated that they fulfilled the biosafety criterion in the mycological aspect. It was shown that potentially antagonistic fungi dominated among these microorganisms. The numerical ratio of these fungi to potential phytopathogens was $15: 1$ in compost I at the end of composting. An even more favorable ratio was found in compost II, where the numerical relationship of antagonists to phytopathogens was 59:1. The greater number of antagonistic fungi compared to the pathogenic ones in compost II results from the higher content of lignocellulosic waste, i.e., sawdust and straw. According to Noble and Coventry [74], this effect is primarily dependent on the chemical composition of the waste used for composting, mainly on the content of lignin and cellulose. Straw used for composting, after preliminary digestion of the external wax layer, provides easily available polysaccharides for cellulolytic enzymes secreted by microorganisms [75]. Trichoderma belongs to fungi known for their ability to degrade cellulose [76]. The presence of antagonistic fungi in composted sawdust was also reported by Eida et al. [77]. Fungi listed as antagonists are also known as metal-tolerant filamentous fungi. In compost II, especially on day 14 , the content of some macro- and micronutrients and heavy metals was significantly lower than in compost I. Such composts may contribute to biological control against plant pathogens [78]. The number of potentially antagonistic fungi increased along with the composting time (Table 6).

\section{Conclusions}

Lignocellulosic waste is often composted or belongs to compost mass components. Their utility value is determined by a number of physico-chemical factors. The content of N, P, 
Table 5 Species composition of fungi in lignocellulosic waste compost

\begin{tabular}{|c|c|c|c|c|c|c|c|}
\hline \multirow[t]{4}{*}{ No. } & \multirow[t]{4}{*}{ Species composition of fungi } & \multicolumn{6}{|l|}{ Variant of composts } \\
\hline & & \multicolumn{3}{|l|}{ Compost I } & \multicolumn{3}{|l|}{ Compost II } \\
\hline & & \multicolumn{6}{|c|}{ Number of isolates over time (weeks) } \\
\hline & & 0 (po $18 \mathrm{~h})$ & 30 & Total & 0 (po $18 \mathrm{~h})$ & 30 & Total \\
\hline 1. & Alternaria alternata (Fr.) Keissl. & 1 & 0 & 1 & 1 & 0 & 1 \\
\hline 2. & Aspergillus fumigatus Fres. & $\begin{array}{l}4 \\
192 \text { (after } 8 \text { weeks) }\end{array}$ & 15 & 19 & $\begin{array}{l}0 \\
479 \text { (after } 8 \text { weeks) }\end{array}$ & 1 & 1 \\
\hline 3. & Aspergillus flavus Link & 0 & 0 & 0 & 0 & 8 & 8 \\
\hline 4. & Aspergillus brasiliensis Varga, Frisvad and Samson & 1 & 7 & 8 & 5 & 6 & 11 \\
\hline 5. & Chaetomium globosum Kunze & 0 & 1 & 1 & 0 & 0 & 0 \\
\hline 6. & Doratomyces sp. & 4 & 0 & 4 & 0 & 0 & 0 \\
\hline 7. & Fusarium oxysporum E.F. Sm. and Swingle & 4 & 0 & 4 & 0 & 0 & 0 \\
\hline 8. & Fusarium solani (Mart.) Sacc. & 3 & 4 & 11 & 1 & 1 & 0 \\
\hline 9. & $\begin{array}{l}\text { Clonosatchys rosea f.catenulata (J.C. Gilman and E.V. Abbott) } \\
\text { Schroers }\end{array}$ & 0 & 0 & 0 & 0 & 27 & 27 \\
\hline 10. & Humicola fusco-astra Traaen & 0 & 0 & 0 & 0 & 1 & 1 \\
\hline 11. & Mucor plumbeus Bonord & 4 & 0 & 4 & 0 & 0 & 0 \\
\hline 12. & Paecilomyces variotti Bainier & 0 & 41 & 41 & 2 & 33 & 35 \\
\hline 13. & $\begin{array}{l}\text { Purpureocillium lilacinum (Thom) Luangsa-ard, Hywel-Jones and } \\
\text { Samson }\end{array}$ & 0 & 0 & 0 & 0 & 1 & 0 \\
\hline 14. & Penicilium brevicompactum Dierckx & 0 & 0 & 0 & 0 & 9 & 9 \\
\hline 15. & Penicillium expansum Link & 0 & 2 & 2 & 0 & 3 & 3 \\
\hline 16. & Penicillium glabrum (Wehmer) Westling & 12 & 0 & 12 & 27 & 0 & 27 \\
\hline 17. & Penicillium nigrescens Jungh. & 0 & 0 & 0 & 1 & 0 & 1 \\
\hline 18 & Penicilium sp. & 0 & 34 & 34 & 1 & 2 & 3 \\
\hline 19. & Penicillium verrucosum Dierckx & 0 & 0 & 0 & 12 & 0 & 12 \\
\hline 20. & Rhinotrichum lanosum Cooke & 0 & 0 & 0 & 0 & 10 & 10 \\
\hline 21. & Rhizopus stolonifer (Ehrenb.) Vuill. & 0 & 1 & 1 & 0 & 0 & 0 \\
\hline 22. & Trichoderma viride Pers. & 16 & 27 & 43 & 18 & 31 & 49 \\
\hline Total & & 49 & 132 & 181 & 68 & 132 & 200 \\
\hline
\end{tabular}

Table 6 The ratio of potentially antagonistic (A) to potentially phytopathogenic fungi (B) during the composting of keratin and lignocellulosic waste

\begin{tabular}{llllllll}
\hline $\begin{array}{l}\text { Experimental time point } \\
\text { (weeks) }\end{array}$ & \multicolumn{2}{l}{ Compost I (PGSF) } & & \multicolumn{3}{l}{ Compost II (PSSF) } \\
\cline { 2 - 3 } \cline { 6 - 8 } & $\mathrm{A}$ & $\mathrm{B}$ & $\mathrm{A}: \mathrm{B}$ & & $\mathrm{A}$ & $\mathrm{B}$ & $\mathrm{A}: \mathrm{B}$ \\
\hline 0 & 16 & 8 & $2: 1$ & & 19 & 2 & $9: 1$ \\
30 & 61 & 4 & $15: 1$ & & 59 & 1 & $59: 1$ \\
Total & 77 & 12 & & 78 & 3 & \\
\hline
\end{tabular}

Potentially antagonistic fungi: Clonosatchys rosea f. catenulata, Trichoderma viride, Penicilium sp.; potentially pathogenic fungi: Alternaria alternata, Fusarium oxysporum, Fusarium solani
$\mathrm{K}$ in composts I contained $42.86 \%$ pine bark, $34.28 \%$ grass, $20.0 \%$ sawdust and $2.86 \%$ chicken feathers and compost II $25.54 \%$ pine bark, $10.63 \%$ wheat straw, $51.07 \%$ sawdust and $12.76 \%$ chicken feathers, which corresponded or exceeded quality requirements for organic fertilizers produced from composting. Lower than permitted concentrations of heavy metals were demonstrated in the solid and aqueous fractions of the tested composts containing pine bark grass, sawdust and chicken feathers (compost I, PGSF), and pine bark, wheat straw sawdust and chicken feathers (compost II, PSSF), thus lignocellulose composts are safe for soil applications. The composts tested were not phytotoxic, because they did not inhibit root growth of the test plant, Lepidium sativum L., and demonstrated a very good phytosanitary status, especially compost II that contained more hard-todegrade lignocellulosic waste. The numerical ratio of these fungi to potential phytopathogens was $15: 1$ in compost I and 59:1 in compost II at the end of composting. Potentially 
antagonistic fungi were represented by the following species: Clonostachys rosea f. catenulata (former Gliocadium catenulatum), Penicillium sp. and T. viride. T. viride in compost I and II and Clonostachys rosea f. catenulata in compost II were among the most frequent potential antagonists. A decrease in the frequency of A. fumigatus, considered as an opportunistic human pathogen, was demonstrated during the composting process of lignocellulosic waste. This is important from a practical point of view. A significant advantage of antagonistic fungi over pathogenic ones may have a decisive impact on maintaining soil and plant health. They were also safe from a sanitary point of view, because they did not contain E. coli bacteria and parasitic eggs. Moreover, the physical properties (field water capacity, bulk density, total porosity) of the both composts were well aerated, which in turn provided a light product, which is important in horticultural production.

Acknowledgements This work was supported by the Ministry of Science and Higher Education in Poland/National Science Centre in Poland, (Grant Number N N523 213737).

Open Access This article is distributed under the terms of the Creative Commons Attribution 4.0 International License (http://creativeco mmons.org/licenses/by/4.0/), which permits unrestricted use, distribution, and reproduction in any medium, provided you give appropriate credit to the original author(s) and the source, provide a link to the Creative Commons license, and indicate if changes were made.

\section{References}

1. Kapdan, I.K., Kargi, F.: Bio-hydrogen production from waste materials. Enzyme Microb. Technol. 38, 569-582 (2006)

2. Kim, S., Dale, B.E.: Global potential bioethanol production from wasted crops and crop residues. Biomass Bioenerg. 26, 361-375 (2004)

3. Peng, X., Nges, I.A., Liu, J.: Improving methane production from wheat straw by digestate liquor recirculation in continuous stirred tank processes. Renew. Energy 85, 12-18 (2016)

4. Kuhad, R.C., Lata, P.C., Singh, A.: Composting of lignocellulosic waste material for soil amendment. In: Singh, A., Parmar, N., Kuhad, R.C. (eds.) Bioaugmentation, Biostimulation and Biocontrol, pp. 107-128. Springer, Heidelberg (2011)

5. Michel, F.C. Jr., Larry, F., Huang, A.J.F., Reddy, C.A.: Effects of turning frequency, leaves to grass mix ratio and windrow vs. pile configuration on the composting of yard trimmings. Compost Sci. Util. 4, 26-43 (1996)

6. Kausar, H., Ismail, M.R., Saud, H.M., Othman, R., Habib, S.: Use of lignocellulolytic microbial consortium and $\mathrm{pH}$ amendment on composting efficacy of rice straw. Compost Sci. Util. 21, 121-133 (2013)

7. Yu, H., Zeng, G., Huang, H., Xi, X., Wang, R., Huang, D., Huang, G., Li, J.: Microbial community succession and lignocellulose degradation during agricultural waste composting. Biodegradation 18, 793-802 (2007)

8. Feng, C.-L., Zeng, G.-M., Huang, D.-L., Hu, S., Zhao, M.-H., Lai, C., Huang, C., Wei, Z., Li, N.: Effect of ligninolytic enzymes on lignin degradation and carbon utilization during lignocellulosic waste composting. Process Biochem. 46, 1515-1520 (2011)

9. Huang, D.-L., Zeng, G.-M., Feng, C.-L., Hu, S., Lai, C., Zhao, M.-H., Su, F.-F., Tang, L., Liu, H.-L.: Changes of microbial population structure related to lignin degradation during lignocellulosic waste composting. Bioresour. Technol. 101, 4062-4067 (2010)

10. Gao, M., Li, B., Yu, A., Liang, F., Yang, L., Sun, Y.: The effect of aeration rate on forced-aeration composting of chicken manure and sawdust. Bioresour. Technol. 101, 1899-1903 (2010)

11. Huang, G.F., Wong, J.W.C., Wu, Q.T., Nagar, B.B.: Effect C/N on composting of pig manure with sawdust. Waste Manag. 24, 805-813 (2004)

12. Tiquia, S.M.: Evolution of extracellular activities during manure composting. J. Appl. Microbiol. 92, 764-770 (2002)

13. Zbytniewski, R., Buszewski, B.: Characterization of natural organic matter (NOM) derived from sewage sludge. Part 1: chemical and spectroscopic properties. Bioresour. Technol. 96, 471-478 (2005)

14. Boulter, J.I., Boland, G.J., Trevors, J.T.: Compost: a study of the development process and end-product potential for suppression of turfgrass disease. World J. Microbiol. Biotechnol. 16, 115-134 (2000)

15. Korniłłowicz-Kowalska, T., Bohacz, J.: The influence of keratin-bark and keratin-bark-straw composts on development of bacteria and fungi in two soils under different plant cultivation systems. Zesz. Problem. Post. Nauk Rol. 506, 245-259 (2005) (in polish)

16. Wu, L., Ma, L.Q., Martinez, G.A.: Comparison of methods for evaluating stability and maturity biosolids compost. J. Environ. Qual. 29, 424-429 (2000)

17. Bohacz, J., Korniłłowicz-Kowalska, T.: Choice of maturity indexes for feathers-plant material composts on a base of selected microbiological and chemical parameters-preliminary research. Pol. J. Environ. Stud. 16, 719-725 (2007)

18. Zucconi, F., Forte, M., Monaco, A., de Bertoldi, M.: Biological evaluation of compost maturity. Biocycle 22, 426-429 (1981)

19. Agnew, J.M., Leonard, J.J.: The physical properties of compost. Compost Sci. Util. 11, 238-264 (2003)

20. Bohacz, J.: Microbial strategies and biochemical activity during lignocellulosic waste composting in relation to the occurring biothermal phases. J. Environ. Manag. 206, 1052-1062 (2018)

21. Mathur, S.P., Owen, G., Dinel, H., Schnitzer, M.: Determination of compost biomaturity. I. Literature review. Biol. Agric. Hortic. 10, 65-85 (1993)

22. Shrestha, K., Walsh, K.B., Midmore, D.J.: Microbially enhanced compost extract: Does it increase solubilisation of minerals and mineralisation of organic matter and thus improve plant nutrition? J. Bioremed. Biodegrad. 3, 149 (2012)

23. Cunha-Queda, A.C., Ribeiro, H.M., Ramos, A., Cabral, F.: Study of biochemical and microbiological parameters during composting of pine and eucalyptus bark. Bioresour. Technol. 98, 3213-3220 (2007)

24. Wong, M.H.: Phytotoxicity of refuse compost during the process of maturation. Environ. Pollut. (Ser. A) 37, 159-174 (1985)

25. Bohacz, J.: Lignocellulose-degrading enzymes, free-radical transformations during composting of lignocellulosic waste and biothermal phases in small-scale reactors. Sci. Total Environ. 580, 744-754 (2017)

26. Klute, A.: Methods of Soil Analysis. 1. Physical and Mineralogical Methods. ASA-SSSA Inc., Madison (1986)

27. Masciandaro, G., Ceccanti, B., Garcia, C.: Soil agro-ecological management: fertirrigation and vermicompost treatments. Bioresour. Technol. 59, 199-206 (1997)

28. Tiquia, S.M., Tam, N.F.Y., Hodgkiss, I.J.: Effects of composting on phytotoxicity of spent pig-manure sawdust litter. Environ. Pollut. 93, 249-256 (1996) 
29. Tam, N.F.Y., Tiquia, S.: Assessing toxicity of spent pig liter using a seed germination technique. Resour. Conserv. Recycl. 11, 261274 (1994)

30. Martin, J.P.: Use of acid rose bengal and streptomycin in the plate method of estimating soil fungi. Soil Sci. 69, 215-233 (1950)

31. Domsch, K.H., Gams, W., Anderson, T.H.: Compendium of Soil Fungi. IHW-Verlag Eching, München (2007)

32. Barnett, H.L., Hunter, B.B.: Illustrated Genera of Imperfect Fungi. Macmillan, New York (1989)

33. van Oorschot, C.A.N.: A revision of Chrysosporium and allied genera. Stud. Mycol. 20, 1-89 (1980)

34. Lashermes, G., Barriuso, E., Le Villio-Poitrenaud, M., Houot, S.: Composting in small laboratory pilots: performance and reproducibility. Waste Manag. 32, 271-277 (2012)

35. Bernal, M.P., Paredes, C., Sánchez-Monedero, M.A., Cegarra, J.: Maturity and stability parameters of composts prepared with a wide range of organic wastes. Bioresour. Technol. 63, 91-99 (1998)

36. Goyal, S., Dhull, S.K., Kapoor, K.K.: Chemical and biological changes during composting of different organic wastes and assessment of compost maturity. Bioresour. Technol. 96, 1584-1591 (2005)

37. Lasaridi, K., Protopapa, J., Kotsou, M., Pilidis, G., Manios, T., Kyriacou, A.: Quality assessment of composts in the Greek market: the need for standards and quality assurance. J. Environ. Manag. 80, 58-65 (2006)

38. Hirai, M.F., Chanyasak, V., Kubota, H.: A standard measurement for compost maturity. Biocycle. 24, 54-56 (1983)

39. Brewer, L.J., Sullivan, D.M.: Maturity and stability evaluation of composted yard trimmings. Compost Sci. Util. 11, 96-112 (2003)

40. Bernal, M.P., Alburquerque, J.A., Moral, R.: Composting of animal manures and chemical criteria for compost maturity assessment. A review. Bioresour. Technol. 100, 5444-5453 (2009)

41. Onwosi, C.O., Igbokwe, V.C., Odimba, J.N., Ifeanyichukwu, E.E., Nwankwoala, M.O., Iroh, I.N., Ezeogu, L.I.: Composting technology in waste stabilization: on the methods, challenges and future prospects. J. Environ. Manag. 190, 140-157 (2017)

42. Gavilanes-Terán, I., Jara-Samaniego, J., Idrovo-Novillo, J., Angeles Bustamante, M., Moral, R., Paredes, C.: Windrow composting as horticultural waste management strategy - a case study in Ecuador. Waste Manag. 48, 127-134 (2016)

43. Iwegbue, C.M.A., Egun, A.C., Emuh, F.N., Isirimah, N.O.: Compost maturity evaluation and its significance to agriculture. Pak. J. Biol. Sci. 9, 2933-2944 (2006)

44. Iglesias-Jiménez, E., Pérez-García, V.: Determination of maturity indices for city refuse composts. Agric. Ecosyst. Environ. 38, 331-343 (1992)

45. Zawadzki, S.: Soil Science. PWRiL, Warszawa (1999) (in polish)

46. Vukobratović, M., Lončarić, Z., Vukobratović, Ž, Mužić, M.: Use of composted manure as substrate for lettuce and cucumber seedlings. Waste Biomass Valoriz. 9, 25-31 (2018)

47. Haynes, R.J., Zhou, Y.-F.: Comparison of the chemical, physical and microbial properties of composts produced by conventional composting or vermicomposting using the same feedstocks. Environ. Sci. Pollut. Res. 23, 10763-10772 (2016)

48. Hannon, J.B., Mason, I.G.: Composting of green waste shredded by a crush/cut roller versus a low speed counter-rotating shear shredder. Compost Sci. Util. 11, 61-71 (2003)

49. Wang, P., Changa, C.M., Watson, M.E., Dick, W.A., Chen, Y., Hoitink, H.A.J.: Maturity indices for composted dairy and pig manures. Soil Biol. Biochem. 36, 767-776 (2004)

50. Ministry of the Environment. Department of Waste Management.: Guidelines on requirements for composting, fermentation and mechanical and biological treatment of wastes (according to the legal status as of December 15), Warsaw (2008) https://www. mos.gov.pl/g2/big/2009_07/ffc492d741b261340b1e263cd1c05c 85.pdf

51. Szwed, A., Bohacz, J.: Enzymatic activity and certain chemical properties of grey-brown podzolic soil (Haplic luvisol) amended with compost of tobacco wastes. Arch. Environ. Prot. 40, 61-73 (2014)

52. Official Journal of the European Union, Commission decision 2006/799/EC.2006: ecological criteria and the related assessment and verification requirements for the award of the community ecolabel to soil improvers. L 325, 28-34 (2006)

53. El-Gohary, A.A., Osman, E.A.M., Khatab, K.A.: Effect of nitrogen fertilization, humic acid and compost extract on yield and quality of rice plants. J. Soil Sci. Agric. Eng. 1, 77-91 (2010)

54. Szewczuk, C., Sugier, D.: General characteristics and types of foliar fertilizers offered on the Polish market. Annales UMCS Sec. E Agric. 64, 29-36 (2009)

55. Ko, H.J., Kim, K.Y., Kim, H.T., Kim, C.N., Umeda, M.: Evaluation of maturity parameters and heavy metal contents in composts made from animal manure. Waste Manag. 28, 813-820 (2008)

56. Luo, Y., Liang, J., Zeng, G., Chen, M., Mo, D., Li, G., Zhang, D.: Seed germination test for toxicity evaluation of compost: Its roles, problems and prospects. Waste Manag. 71, 109-114 (2018)

57. El-Nagerabi, S.A.F., Elshafie, A.E., AlRawahi, H.S.: Physicochemical and microbial characteristics of locally processed green waste composts. Compost Sci. Util. 20, 120-127 (2012)

58. Selim, Sh.M., Zayed, M., Atta, H.M.: Evaluation of phytotoxicity of compost during composting process. Nat. Sci. 10, 69-76 (2012)

59. Tiquia, S.M.: Reduction of compost phytotoxicity during the process of decomposition. Chemosphere 79, 506-520 (2010)

60. Stachowiak, B., Czarnecki, Z., Trojanowska, K., Gulewicz, K.: Possibilities of composts using in biological plant protection. J. Res. Appl. Agric. Eng. 61, 171-177 (2006)

61. Raj, D., Antil, R.S.: Evaluation of maturity and stability parameters of composts prepared from agro-industrial wastes. Bioresour. Technol. 102, 2868-2873 (2011)

62. Cui, H.-Y., Zhao, Y., Chen, Y.-N., Zhang, X., Wang, X.-Q., Lu, Q., Jia, L.-M., Wei, Z.-M.: Assessment of phytotoxicity grade during composting based on EEM/PARAFAC combined with projection pursuit regression. J. Hazard. Mater. 326, 10-17 (2017)

63. Ros, M., Pascual, J.A., Garcia, C., Hernandez, M.T., Insam, H.: Hydrolase activities, microbial biomass and bacterial community in a soil after long-term amendment with different composts. Soil Biol. Biochem. 38, 3443-3452 (2006)

64. Said-Pullicino, D., Erriquens, F.G., Gigliotti, G.: Changes in the chemical characteristics of water-extractable organic matter during composting and their influence on compost stability and maturity. Bioresour. Technol. 98, 1822-1831 (2007)

65. Gramacki, J., Gramacki, A.: Statistical detection of correlations in data. Telecommun. Rev. LXXXI 6, 711-713 (2008) (in polish)

66. Dąbrowska, G., Hrynkiewicz, K., Kłosowska, K., Trejgell, A., Mierek-Adamska, A.: The effect of rhizobacteria on germination of Brassica napus L. seeds in the presence of heavy metals $(\mathrm{Cd}$, $\mathrm{Cu}, \mathrm{Pb}, \mathrm{Zn}$ ). Oilseed Crops, 31, 86-97 (2010) (in polish)

67. Hoitink, H.A.J., Stone, A.G., Han, D.Y.: Suppression of plant diseases by composts. HortScience 32, 184-187 (1997)

68. Korniłłowicz, T.: Effects of soil fungi (micromycetes) on plant pathogens and pests and their practical aspect. Fragm. Agron. XVII 2(66), 135-154 (2000)

69. Ashraf, R., Shahid, F., Ali, T.A.: Association of fungi, bacteria and actinomycetes with different composts. Pak. J. Bot. 39, 2141$2151(2007)$

70. Fischer, J.L., Beffa, T., Lyon, P.-F., Aragno, M.: Aspergillus fumigatus in windrow composting: effect of turning frequency. Waste Manag. Res. 16, 320-329 (1998) 
71. Krikštaponis, A., Lugauskas, A., Krysińska-Traczyk, E., Prażmo, Z., Dutkiewicz, J.: Enzymatic activities of Aspergillus fumigatus strain isolated from the air at waste landfills. Ann. Agric. Environ. Med. 8, 227-234 (2001)

72. Lugauskas, A., Krikštaponis, A., Šveistyte, L.: Airborne fungi in industrial environments-potential agents of respiratory diseases. Ann. Agric. Environ. Med. 11, 19-25 (2004)

73. Franceschini, S., Chitarra, W., Pugliese, M., Gisi, U., Garibaldi, A., Gullino, M.L.: Quantification of Aspergillus fumigatus and enteric bacteria in European compost and biochar. Compost Sci. Util. 24, 20-29 (2016)

74. Noble, R., Coventry, E.: Suppression of soil-borne plant diseases with composts: a review. Biocontrol Sci. Technol. 15, 3-20 (2005)

75. Wright, C., Gryganskyi, A.P., Bonito, G.: Fungi in composting. In: Purchase, D. (eds.) Fungal applications in Sustainable Environmental Biotechnology, pp. 3-28. Springer, Cham (2016)
76. Viesturs, U., Leite, M., Treimanis, A., Eremeeva, T., Apsite, A., Eisimonte, M., Jansons, P.: Production of cellulases and xylananses by Trichoderma viride and biological processing of lignocellulose and recycled paper fibres. Appl. Biochem. Biotechnol. 57/58, 349-360 (1996)

77. Eida, M.F., Nagaoka, T., Wasaki, J., Kouno, K.: Evaluation of cellulolytic and hemicellulolytic abilities of fungi isolated from coffee residue and sawdust composts. Microbes Environ. 26, 220-227 (2011)

78. Boulter, J.I., Boland, G.J., Trevors, J.T.: Compost: a study of the development process and end-product potential for suppression of turgrass disease. World J. Microbiol. Biotechnol. 16, 115-134 (2000) 